\title{
New data on plume moths (Lepidoptera: Pterophoridae) of Panama. Communication 2
}

\author{
Новые сведения о пальцекрылках (Lepidoptera: Pterophoridae) \\ Панамы. Сообщение 2
}

\author{
V.N. Kovtunovich ${ }^{1}$, P.Ya. Ustjuzhanin ${ }^{2,3,5^{*}}$, A.O. Kozlov ${ }^{4}$ \\ В.Н Ковтунович ${ }^{1}$, П.Я Устюжканин ${ }^{2,3,5^{*}}$, А.О. КозАов ${ }^{4}$
}

\footnotetext{
${ }^{1}$ Moscow Society of Nature Explorers, Bolshaya Nikitskaya 2, Moscow, RU-125009, Russia, E-mail: vasko-69@mail.ru

1 Московское общество испытателей природы, Большая Никитская 2, Москва 125009, Россия.

2 Altai State University, Lenina 61, Barnaul, RU-656049, Russia, E-mail: petrust@mail.ru.

2 Алтайский государственный университет, пр. Ленина 61, Барнаул 656049, Россия.

${ }^{3}$ Biological Institute, Tomsk State University, Lenina Prospekt 36, Tomsk 634050, Russia, E-mail: petrust@mail.ru.

3 Биологический институт, Томский университет, Проспект Ленина 36, Томск 634050, Россия.

${ }^{4}$ Novocheryomushkinskaya 50, Moscow 117418, Russia, E-mail: kant.klintsy@mail.ru.

${ }^{4}$ ул. Новочерёмушкинская, 50, Москва 117418, Россия.

* Corresponding author.
}

KEY WORDS: Pterophoridae, Central America, Panama, new species, new data.

КЛЮЧЕВЫЕ СЛОВА: Pterophoridae, Центральная Америка, Панама, новые виды, новые данные.

ABSTRACT. The second message on plume moths of Panama provides additional materials collected by A. Kozlov and his colleagues in 2018-2019. Two species, new to science, are described: Hellinsia tatianae Kovtunovich et Ustjuzhanin sp.n. and Hellinsia dietrichorum Kovtunovich et Ustjuzhanin sp.n. Additionally, 9 species new to the fauna of Panama, are indicated.

РЕЗЮМЕ. Во втором сообщении о пальцекрылках Панамы приводятся дополнительные материалы, собранные А. Козловым с коллегами в 2018 2019 гг. Описываются два новых вида для науки: Hellinsia tatianae Kovtunovich et Ustjuzhanin sp.n. и Hellinsia dietrichorum Kovtunovich et Ustjuzhanin sp.n. и приводятся 9 видов, новых для фауны Панамы.

In our first message on Pterophoridae of Panama, 15 species were indicated [Kovtunovich, Ustjuzhanin, 2018]. New material from Panama, collected by A. Kozlov and Yu. Kovaleva, allows to significantly enlarge the species composition of Pterophoridae, which currently includes 26 species, two of which are described as new to science and nine - as new to the fauna of Panama (marked with an *).

The holotypes of the new species and part of the paratypes are deposited in the collection of Zoological Museum of St.-Petersburg (ZISP).

\section{List of species}

*Leptodeuterocopus trinidad Gielis, 1996

MATERIAL EXAMINED. $10^{7}$, PANAMA. Chiriqui province, near Volcan town, Totumas Mountain Cloud Forest, $8^{\circ} 53^{\prime} \mathrm{N}$, $82^{\circ} 41^{\prime} \mathrm{W}, \mathrm{h}-1920$ m, v-vi. 2018, A. Kozlov \& Yu. Kovaleva.

DISTRIBUTION. Trinidad, Panama.

Marasmarcha brevirostris (Walsingham, 1915)

MATERIAL EXAMINED. 1 , PANAMA. Chiriqui province, near Volcan town, Totumas Mountain Cloud Forest, $8^{\circ} 53^{\prime} \mathrm{N}$, $82^{\circ} 41^{\prime} \mathrm{W}, \mathrm{h}-1920$ m, 28.iv-02.v.2019, A. Kozlov \& Yu. Kovaleva.

DISTRIBUTION. Mexico, Guatemala, Panama

*Hellinsia beneficus (Yano et Heppner, 1983)

MATERIAL EXAMINED. 1 ○', PANAMA. Chiriqui province, near Volcan town, Totumas Mountain Cloud Forest, $8^{\circ} 53^{\prime} \mathrm{N}$, $82^{\circ} 41^{\prime} \mathrm{W}, \mathrm{h}-1920 \mathrm{~m}$, v-vi. 2018; 3 o $^{\top} \sigma^{7}, 3$ 우, 28.iv-02.v.2019, A. Kozlov \& Yu. Kovaleva.

DISTRIBUTION. Mexico, Hawaii Islands, Panama.

*Hellinsia calais (Meyrick, 1930)

MATERIAL EXAMINED. $1 \sigma^{7}$, PANAMA. Chiriqui province, near Volcan town, Totumas Mountain Cloud Forest, $8^{\circ} 53^{\prime} \mathrm{N}$, $82^{\circ} 41^{\prime}$ W, h -1920 m, 24-27.v.2019, A. Kozlov \& Yu. Kovaleva.

DISTRIBUTION. Brazil, Costa Rica, Panama.

*Hellinsia fissuralba Gielis, 1996

MATERIAL EXAMINED. $10^{7}$, PANAMA. Chiriqui province, near Volcan town, Totumas Mountain Cloud Forest, $8^{\circ} 53^{\prime} \mathrm{N}$, $82^{\circ} 41^{\prime} \mathrm{W}, \mathrm{h}-1920$ m, 24-27.v.2019, A. Kozlov \& Yu. Kovaleva. DISTRIBUTION. Peru, Mexico, Panama.

How to cite this article: Kovtunovich V.N., Ustjuzhanin P.Ya., Kozlov A.O. 2019. New data on plume moths (Lepidoptera: Pterophoridae) of Panama. Communication 2 // Russian Entomol. J. Vol.28. No.4. P.433-436. doi: 10.15298/rusentj.28.4.12 
*Hellinsia (?) fusciciliata (Zeller, 1877)

MATERIAL EXAMINED. $30^{7} \sigma^{7}, 9$ $9 \circ$, PANAMA. Chiriqui province, near Volcan town, Totumas Mountain Cloud Forest, $8^{\circ} 53^{\prime} \mathrm{N}, 82^{\circ} 41^{\prime} \mathrm{W}, \mathrm{h}-1920 \mathrm{~m}$, v-vi. 2018; 5 ex, 28.iv-02.v.2019, 1 ○', 14-16.v.2019, 1 ○', 24-17.v.2019, A. Kozlov \& Yu. Kovaleva.

DISTRIBUTION. Colombia, Costa Rica, Venezuela, Panama.

*Hellinsia obscuricilia Arenberger et Wojtusiak, 2001

MATERIAL EXAMINED. $2 \sigma^{7} \sigma^{7}$, PANAMA. Chiriqui province, near Volcan town, Totumas Mountain Cloud Forest, $8^{\circ} 53^{\prime} \mathrm{N}$, $82^{\circ} 41^{\prime} \mathrm{W}, \mathrm{h}-1920 \mathrm{~m}$, v-vi. 2018, A. Kozlov \& Yu. Kovaleva.

DISTRIBUTION. Venezuela, Costa Rica, Bolivia, Panama.

\section{*Hellinsia pizarroi Gielis, 2011}

MATERIAL EXAMINED. 2 우, PANAMA. Chiriqui province, near Volcan town, Totumas Mountain Cloud Forest, $8^{\circ} 53^{\prime} \mathrm{N}$, $82^{\circ} 41^{\prime} \mathrm{W}, \mathrm{h}-1920 \mathrm{~m}, \mathrm{v}-\mathrm{vi} .2018$; $1 \mathrm{O}^{\text {’ }}$, 28.iv-2.v.2019, 1 ㅇ, 2427.v.2019, A. Kozlov \& Yu. Kovaleva.

DISTRIBUTION. Ecuador, Paraguay, Panama.

\section{Hellinsia phloeochroa (Walsingham, 1915)}

MATERIAL EXAMINED. $1 \sigma^{\top}, 4$ +9 , PANAMA. Chiriqui province, near Volcan town, Totumas Mountain Cloud Forest, $8^{\circ} 53^{\prime} \mathrm{N}, 82^{\circ} 41^{\prime} \mathrm{W}, \mathrm{h}-1920$ m, v-vi. 2018, A. Kozlov \& Yu. Kovaleva. zuela.

DISTRIBUTION. Mexico, Guatemala, Panama, Vene-

\section{Hellinsia tatianae Kovtunovich et Ustjuzhanin, sp.n.} Figs 1-3.

TYPE MATERIAL. Holotype: $0^{7}$, (ZISP, gen.pr. Nr. 1918), PANAMA. Chiriqui province, near Volcan town, Totumas Mountain Cloud Forest, $8^{\circ} 53^{\prime} \mathrm{N}, 82^{\circ} 41^{\prime} \mathrm{W}, \mathrm{h}-1920 \mathrm{~m}$, v-vi.2018. Paratypes: $2 \sigma^{7} \sigma^{7}$, 28.iv-02.v.2019; $2 \sigma^{7} \sigma^{7}, 1$ o, 24-27.v.2019, same data as holotype, A. Kozlov \& Yu. Kovaleva (ZISP, CUK).

DESCRIPTION. External characters. Forehead is covered in pale yellow hair, collar is colored brown, thorax and tegulae are white. Labial palpi is thin, short, slightly tapered apically, equal to longitudinal eye diameter. Antennas are pale yellow. Wingspan length is $21 \mathrm{~mm}$. Fore wing is colored pale yellow. Stretching from cleft base to costal edge, there is an oblique brown stroke. On two first lobes of fore wing apical parts there are fine but clear brown horizontal strokes: one on the first lobe, three on the second. On a fringe of an outer edge, fore wing in the middle is covered in brown scales. On the inside cleft the fringe is pale yellow, along an outer edge is slightly darkened with pale brown hairs. Hind wings are grey, noticeably darker than fore wings, with monochrome grey fringe. Legs are pale yellow, almost white.

Male genitalia. Valves are asymmetric, narrow. At the base of a left valve there is an harpe, bent at right angle. Saccular process in distal part of right valve is thin and sharpened as a slightly concave needle. Anellus arms are of unequal length, right one is slightly longer and wider. Saccus has an arc form. Uncus is narrow. Aedeagus is thin, slightly concave, twice shorter than valve in length.

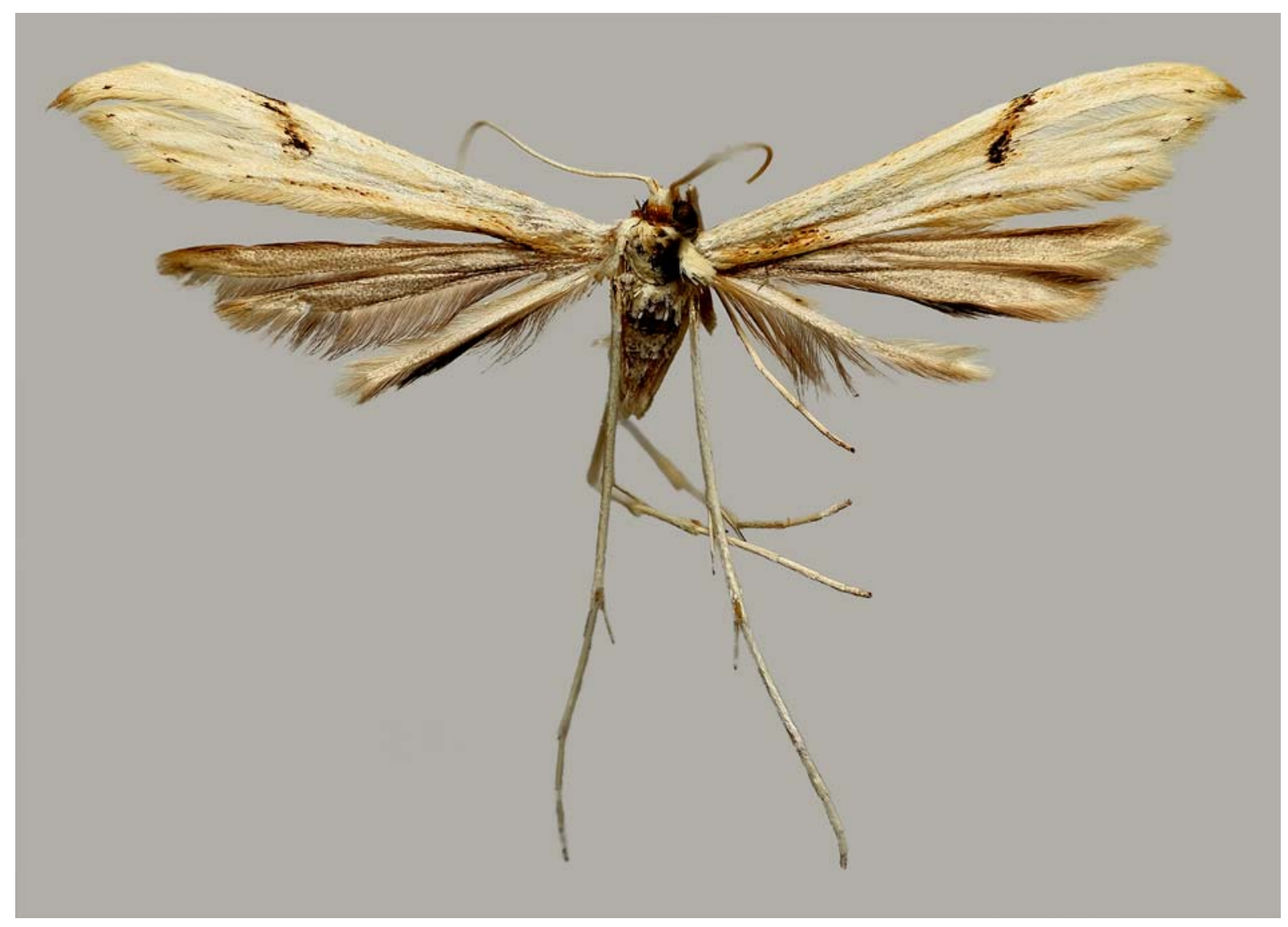

Fig. 1. Hellinsia tatianae sp.n., male, holotype.

Pис. 1. Hellinsia tatianae sp.n., самец, голотип. 


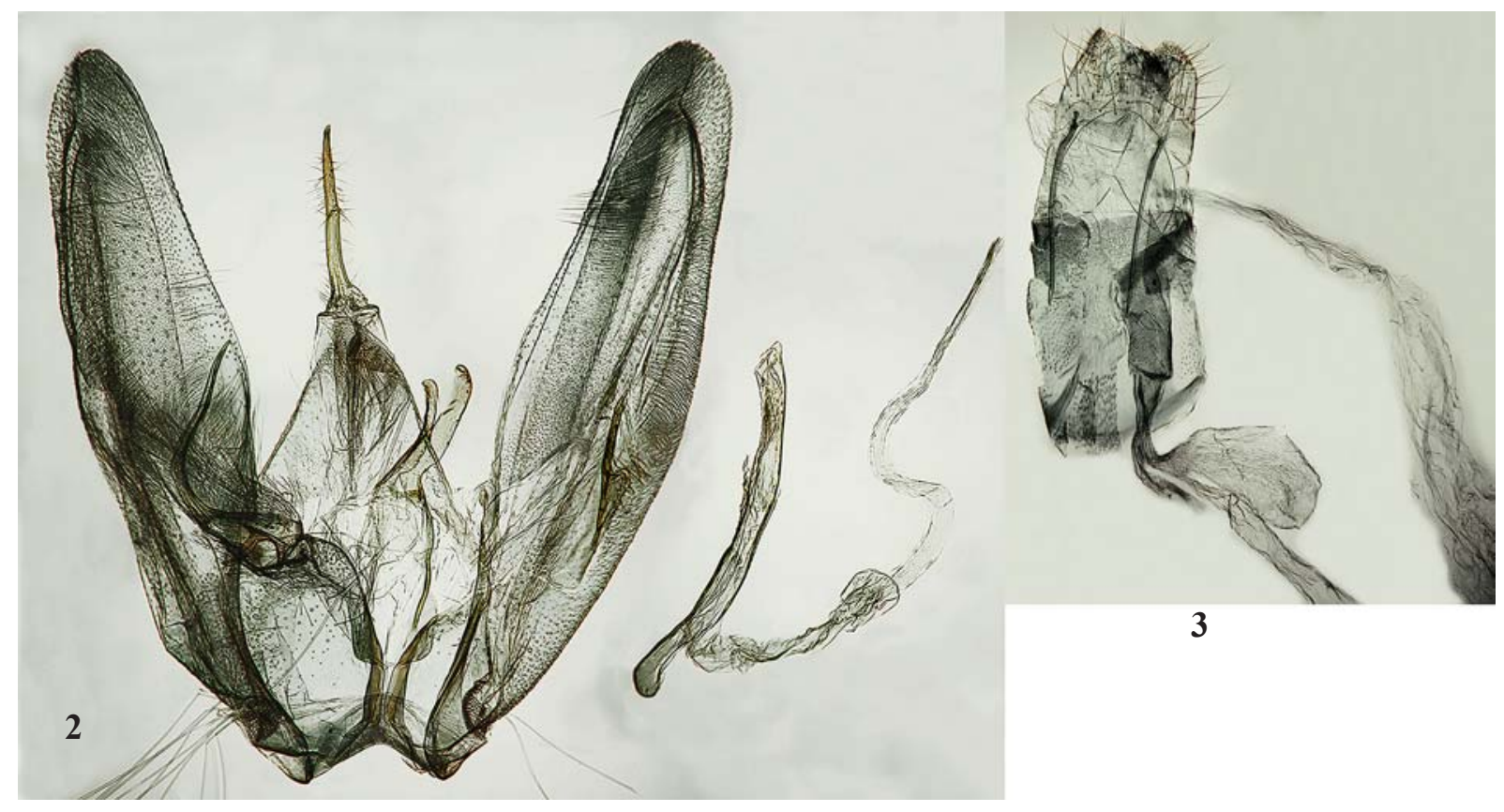

Figs 2-3. Hellinsia tatianae sp.n.: 2 - male genitalia, holotype (ZISP, gen.pr. Nr.1918); 3 - female genitalia, paratype (ZISP, gen.pr. Nr.1917).

Рис. 2-3. Hellinsia tatianae sp.n.: 2 - гениталии самца, голотип (ZISP, gen.pr. Nr.1918); 3 - гениталии самки, паратип (ZISP, gen.pr. Nr.1917).

Female genitalia. Antrum is cylindrical, passing into short ductus bursae. Bursa copulatrix is oval with a small signum. Ductus seminalis is narrow and long. Posterior apophyses are thin, twice longer than papillae anales. No anterior apophyses.

DIAGNOSIS. In the male genitalia, by the shape of the harpe on the left valve and by the anellus arms, the new species is similar to Hellinsia angulofuscus (Gielis, 1991), but differs by the thin sharp saccular process in the distal part of the right valve.

ETYMOLOGY. The species is named after Tatiana Dmitrievna Demchenko, the grandmother of the third author.

\section{Hellinsia dietrichorum Kovtunovich et Ustjuzhanin, sp.n. Figs 4-5.}

TYPE MATERIAL. Holotype: $\sigma^{7}$, (ZISP, gen.pr. Nr. 1919), PANAMA. Chiriqui province, near Volcan town, Totumas Mountain Cloud Forest, $8^{\circ} 53^{\prime} \mathrm{N}, 82^{\circ} 41^{\prime} \mathrm{W}, \mathrm{h}-$ 1920 m, v-vi. 2018, A. Kozlov \& Yu. Kovaleva.

DESCRIPTION. External characters. White hairs on forehead, the collar is dark brown. Thorax and tegulae are white. Labial palpi is thin, short, slightly tapered apically, equal to eye diameter in length, pale outside, brown inside. Antennas are pale yellow. Wingspan is $20 \mathrm{~mm}$. Fore wing is pale yellow. Oblique brown stroke stretching from cleft base to costal edge. Small dark brown spot in first third of a fore wing. Apical part of a first lobe is framed in fine longitudinal brown strokes. Inside the cleft, fringe is yellowish-grey. Hind wings are grey, noticeably darker than fore wings, the fringe is monochrome grey. Leg are yellowish-grey. Spurs on legs of unequal length, outer spur is shorter than inner one, bases of spurs darkened with brown scales.

Male genitalia. Valves are asymmetric, narrow. Harpe on left valve is thin, long, noticeably protruding over valve apex. Saccular process on right valve is thin, bluntly rounded apically, extending almost to apex of a valve. Anellus arms are long, of unequal width, right one is slightly wider than left one. Saccus has an arc form. Uncus is narrow, arc formed. Aedeagus thin, almost straight, more than twice shorter than valve in length.

Female unknown.

DIAGNOSIS. In the male genitalia, by the harpe on the right valve, the anellus arms and the aedeagus, the new species is similar to Hellinsia shishkini Kovtunovich, Ustjuzhanin et Sinyaev, 2018, but differs in the sacculus shape, in the pale yellow color of the fore wings with the oblique brown stroke and in the dark grey color of the hind wings, while in $H$. shishkini, all the wings are unicolorous silver-white without similar strokes.

ETYMOLOGY. The species as named after Jeffrey and Alma Dietrich for their invaluable assistance provided during the entomological research.

*Oidaematophorus trachyphloeus (Meyrick, 1926)

MATERIAL EXAMINED. $2 \sigma^{7} \sigma^{7}, 2$ +9 , PANAMA. Chiriqui province, near Volcan town, Totumas Mountain Cloud Forest, $8^{\circ} 53^{\prime} \mathrm{N}, 82^{\circ} 41^{\prime} \mathrm{W}, \mathrm{h}-1920 \mathrm{~m}$, v-vi. 2018; 1 ㅇ, 14-16.v.2019, A. Kozlov \& Yu. Kovaleva.

DISTRIBUTION. Costa Rica, Guatemala, Panama.

\section{*Singularia mayaensis Gielis, 2011}

MATERIAL EXAMINED. $10^{7}$, PANAMA. Chiriqui province, near Volcan town, Totumas Mountain Cloud Forest, $8^{\circ} 53^{\prime} \mathrm{N}$, $82^{\circ} 41^{\prime} \mathrm{W}, \mathrm{h}-1920$ m, v-vi. 2018, A. Kozlov \& Yu. Kovaleva.

DISTRIBUTION. Costa Rica, Panama.

Acknowledgments. The authors express their sincere gratitude to Yulia A. Kovaleva (Moscow, Russia) for the assistance in collecting plume moths in Panama. The third author is also grateful to Jeffrey and Alma Dietrich (Chiriqui province, Panama) for hospitality and assistance in collecting the specimens. 


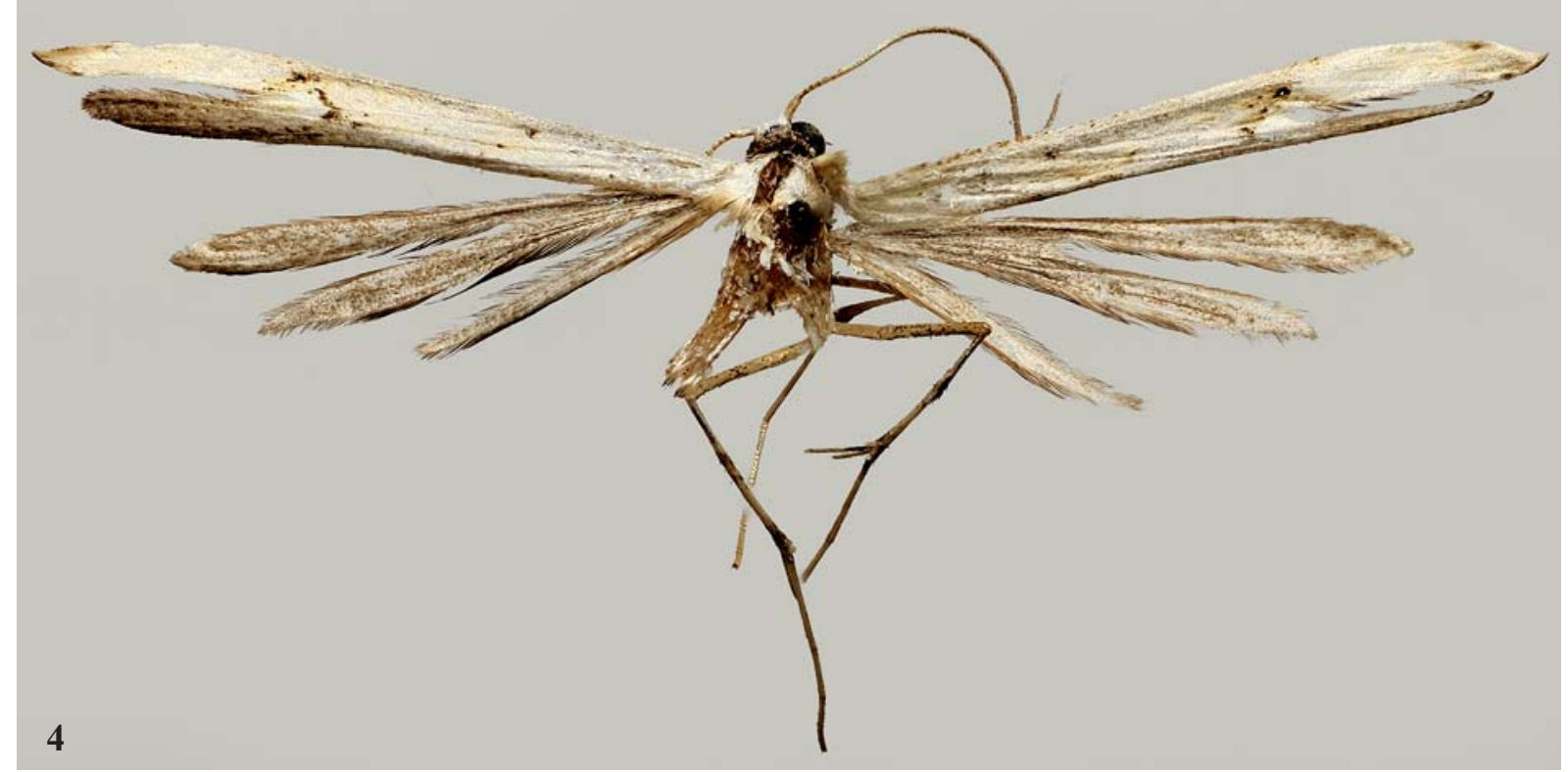

4

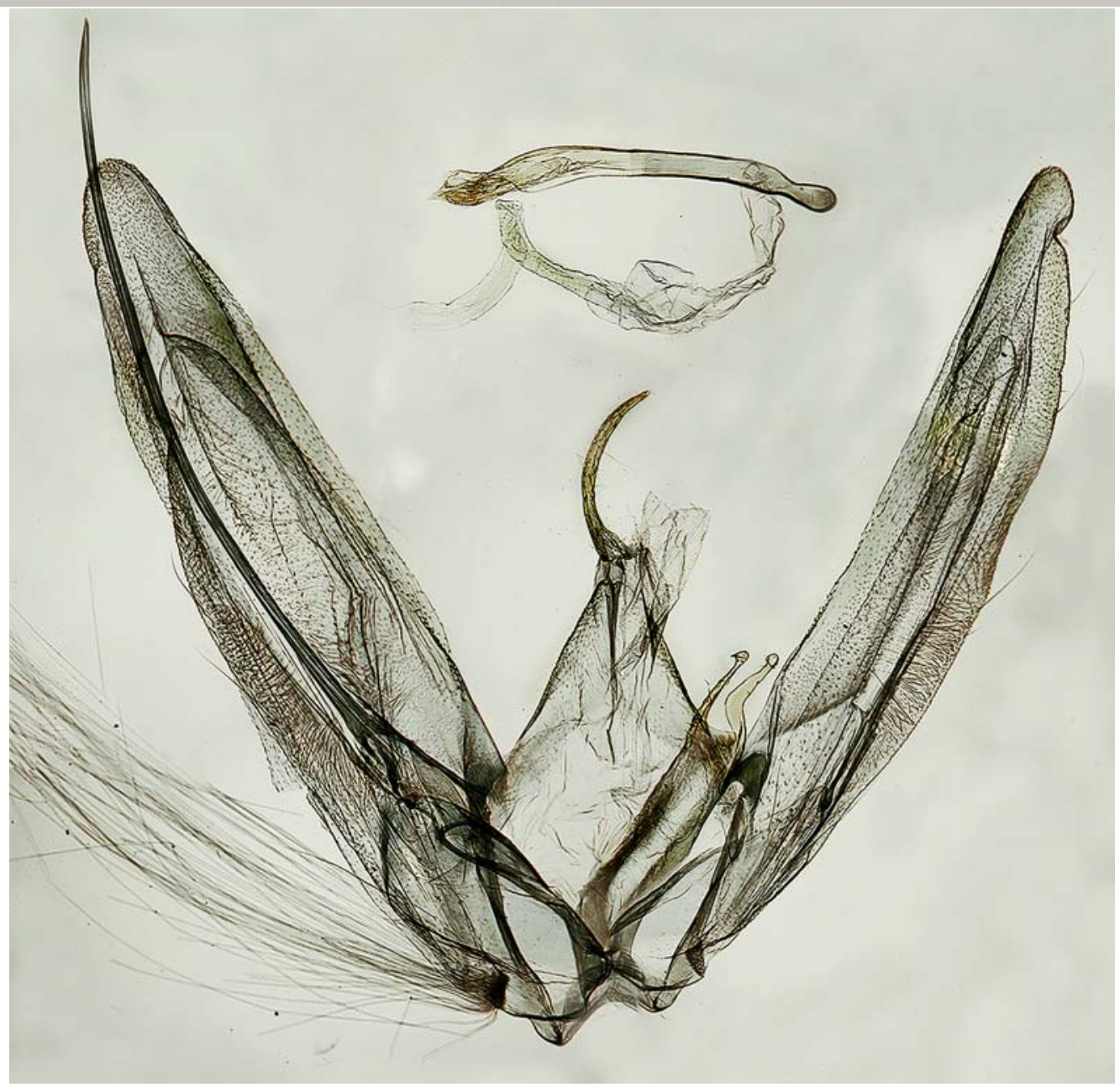

\section{References}

Figs 4-5. Hellinsia dietrichorum sp.n. 4 - male, holotype; 5 male genitalia, holotype (ZISP, gen.pr. Nr.1919).

Рис. 4-5. Hellinsia dietrichorum sp.n. 4 - самец, голотип; 5 - гениталии самца, голотип (ZISP, gen.pr. Nr.1919).
Kovtunovich V.N., Ustjuzhanin P.Ya. 2018. New data on plume moths (Lepidoptera: Pterophoridae) of Panama // Russian Entomological Journal. Vol.27. No.2. P.99-201. 